\title{
Pilonidal sykdom - en underprioritert lidelse
}

I dette nummer av Tidsskriftet omtaler Rushfeldt \& Søreide kirurgiske behandlingsalternativer ved pilonidal sykdom (1), en vanlig tilstand som oftest rammer unge menn. Det finnes en rekke kirurgiske metoder, og kunnskapsgrunnlaget er svakt når man skal finne den optimale. I artikkelen presenteres alternativene, og ved elektiv operasjon er det sannsynlig at en asymmetrisk hudplastikk med primær lukning av såret gir minst risiko for residiv og best resultat.

Denne sykdommen har kanskje ikke høy status i det kirurgiske fagmiljøet. Operasjonene anses som enkle og blir gjerne overlatt til yngre assistentleger. Sannsynligvis blir det fortsatt ofte utført en symmetrisk, vid eksisjon av hud og underhud helt ned til halebeinet, slik mange av oss lærte det tidlig i vår kirurgiske karriere.

Metoden fører ofte til infeksjon og forsinket tilheling enten såret lukkes primært eller blir lagt åpent. Med noen få unntak $(2,3)$ er det publisert lite om behandlingsresultatene i Norge. Det er grunn til å tro at kvalitetssikringen av kirurgisk behandling av pilonidal sykdom kunne vært langt bedre. Interesse for tilstanden, en klar erkjennelse av hvor ofte tradisjonelle kirurgiske metoder svikter samt vektlegging av moderne kirurgiske metoder er viktig dersom resultatene skal bli bedre.

Indikasjonene for kirurgisk behandling er ikke drøftet spesielt $i$ artikkelen, men trenger en særlig grundig vurdering. At akutte abscesser skal dreneres, er ikke kontroversielt. Spørsmålet er hvordan pasienter med kroniske problemer, vanligvis intermitterende sekresjon fra sinus i rima internates og varierende ømhet, skal håndteres (4). Rikelig hårvekst, dårlig hygiene, trykk mot området og adipositas antas å disponere for utvikling av sykdommen og ha betydning for hvor mye symptomer pasienten har. Derfor bør fjerning av hår og debris i sinus etterfulgt av repetert hårfjerning og forbedring av hygiene alltid være første trinn i behandlingen ved kronisk sykdom. De som etter dette har beskjedne symptomer, behøver kanskje ikke annen behandling. Ved fortsatte plagsomme symptomer kan fornyet debridement av sinus fulgt av instillasjon av fenol forsøkes. Fenolbehandling er problematisk. Behandlingen medfører vond lukt, kan være smertefull og kan skade omgivende hud. På den annen side er den godt dokumentert, og korrekt gjennomført gir den tilheling hos $60-90 \%$ av pasientene (5).

All kirurgisk behandling medfører risiko for vedvarende postoperative smertetilstander. Det gjelder selv hos pasienter der det ikke kan påvises spesifikke kirurgiske komplikasjoner. Tilstanden antas å skyldes langvarige forandringer av nervesystemets funksjon med perifer og sentral sensitivisering (plastiske forandringer) (6). Selv etter enkle inngrep kan dette oppstå (7). For eksempel har $10-20 \%$ av alle som opereres for lyskebrokk smerter i operasjonsområdet 1-2 år etter operasjonen, og hos noen vedvarer dette livet ut. Dette forhold bør også vektlegges når kirurgi for pilonidal sykdom overveies. I et materiale fra Oslo universitetssykehus, Aker rapporterte $35 \%$ av pasientene som oppnådde full tilheling etter operasjonen at de likevel hadde smerter og ubehag fra området (2). Hos dem som var operert med en asymmetrisk rombeplastikk, var tallet $58 \%$. I tillegg syntes noen at arret var kosmetisk skjemmende.
Vi savner en godt designet randomisert studie der man sammenlikner optimal ikke-operativ behandling med en god kirurgisk metode hos pasienter med kronisk pilonidal sykdom. Inntil videre mener jeg at vi bør anbefale initial konservativ behandling og at kirurgi reserveres for de som fortsatt har plagsomme symptomer. Dersom kirurgi er indisert, gis det i oversiktsartikkelen en god veiledning i valg av metode.

\section{Arild Nesbakken}

arild.nesbakken@medisin.uio.no

Arild Nesbakken (f. 1950) er overlege ved Gastroenterologisk kirurgisk avdeling, Oslo universitetssykehus, Aker, professor II ved Det medisinske fakultet, Universitetet i Oslo og Clinical associate ved Centre for Cancer Biomedicine, Oslo Universitetssykehus.

\section{Oppgitte interessekonflikter: Ingen}

\section{Litteratur}

1. Rushfeldt C, Søreide K. Kirurgisk behandling av pilonidal sykdom. Tidsskr Nor Legeforen 2010; 130: 936-9.

2. Hølmebakk T, Nesbakken A. Surgery for pilonidal disease. Scand J Surg 2005; 94: $43-6$.

3. Søndenaa K, Nesvik I, Andersen E et al. Recurrent pilonidal sinus after excision with closed or open treatment: final result of a randomised trial. Eur J Surg 1996 ; $162: 237-40$

4. Humphries AE, Duncan JE. Evaluation and management of pilonidal disease. Surg Clin North Am 2010: 90: 113-24.

5. Cuneyt $\mathrm{K}$, Cemalettin A. Review of phenol treatment in sacrococcygeal pilonidal disease. Tech Coloproctol 2009; 13: 189-93

6. Stubhaug A. Can opioids prevent post-operative chronic pain? Eur J Pain 2005; 9: 153-6.

7. Macrae WA. Chronic pain after surgery. Br J Anaesth 2001; 87: 88-98. 